Egyptian Journal of Aquatic Biology \& Fisheries

Zoology Department, Faculty of Science,

Ain Shams University, Cairo, Egypt.

ISSN $1110-6131$

Vol. 24(6): 377 - 390 (2020)

www.ejabf.journals.ekb.eg

\title{
Intertidal variation of macrobenthos in a saltmarsh habitat, Noakhali coast, Bangladesh
}

\author{
Md. Akram Ullah, Md. Shafawat Hossain, M. Belal Hossain* and \\ Mahbubur Rahman \\ Department of Fisheries and Marine Science, Noakhali Science and Technology University, \\ Noakhali-3814, Bangladesh
}

*Corresponding Author: mbhnstu@gmail.com

\section{ARTICLE INFO}

Article History:

Received: Aug. 17, 2020

Accepted: Sept. 21, 2020

Online: Sept. 24, 2020

\section{Keywords:}

Macrobenthos,

Physico-chemical

factors,

Saltmarsh,

Intertidal variation.

\section{INTRODUCTION}

Bangladesh is located at the apex of the world's largest bay, the Bay of Bengal, which is in the Southern part of Bangladesh. It is blessed with an extensive coastline of about 710 $\mathrm{km}$ with rich biodiversity (Pramanik,1988). The southeastern and southwestern bank of this nation is generally secured by a complex estuarine biological system with strong interactions of biotic and abiotic factors. The primary estuarine frameworks of the nation are Karnaphuly, Brahmaputra-Meghna (Gangetic delta), Bakkhali, Matamuhuri, and Naf 
rivers (Sarker et al., 2016). The changes in benthic species composition, distribution and abundances relatively could aid as an alarm system and even vest the quantification of environmental transition. For that reason, the benthic communities act as a biological sentinel and crucial targets for bio-monitoring programs worldwide (Hutchinson et al., 1993; Palmer et al., 1997; Cekanovskaia,1962; Japoshvili, 2015).

Benthos is known as the indicators of past and present environmental conditions of an ecosystem more effectively than physical and chemical indices of water and sediment, and are regarded as the best indicators of pollution as they are sedentary sessile, longlived and easily collectible (McLusky and Elliot, 2006). The operations of benthic macrofauna in the aquatic ecosystem make dynamic sediment mosaic, effectively transports solutes into burrows, increment oxygenation of sediment, stimulate microflora and increase disintegration rates (Jones et al., 1994). This decides that these invertebrate species act as ecosystem engineers (Gogina and Zettler, 2010). They have considerable importance in the aquatic food chain and especially the main food sources of commercially important demersal fishes (Hossain et al., 2009). Benthic organisms are also used as an indicator of pollution. Benthic organisms living in the estuarine and marine nearshore ecosystem are important to environmental changes and may nurse as the monitor of changes occurring in the coastal regions (Warwick and Clark, 1993). Benthic organisms have an important role in negotiating physico-chemical processes near the sediment-water interface and in interstitial water, including the degradation of organic matter, metabolisms and dispersion of contaminants such as trace metals and oil derivatives (Snelgrove, 1998).

Saltmarsh is a very suitable model system to examine the ecological effect very across physical and gradients in the coastal system. Saltmarsh exhibits complex habitat structure and biotic zonation. Noakhali is one of the coastal districts at the fringe of the Bay of Bengal with vast char land of recent origin in the south. In Noakhali coast, Noler Char contains a wide range of saltmarsh areas which are very rich in benthic infaunal communities, that are continuously flooded with the tide. These saltmarshes are marshy areas founded near the Meghna river estuary. The habitats of this region for the communities of salt-tolerant vegetation, a wide range of infaunal and epifaunal invertebrates, and low tide and high tide visitors such as fish and water birds.

\section{MATERIALS AND METHODS}

\section{Study area and sampling station}

The study was conducted in the saltmarsh area of the intertidal zone of the Meghna river estuary along the Noakhali coast during December 2018. At site three saltmarshes (S1= station one, $\mathrm{S} 2=$ station two and $\mathrm{S} 3=$ station three) were randomly selected (Figure 1). The sampling stations were designated by using GPS. 


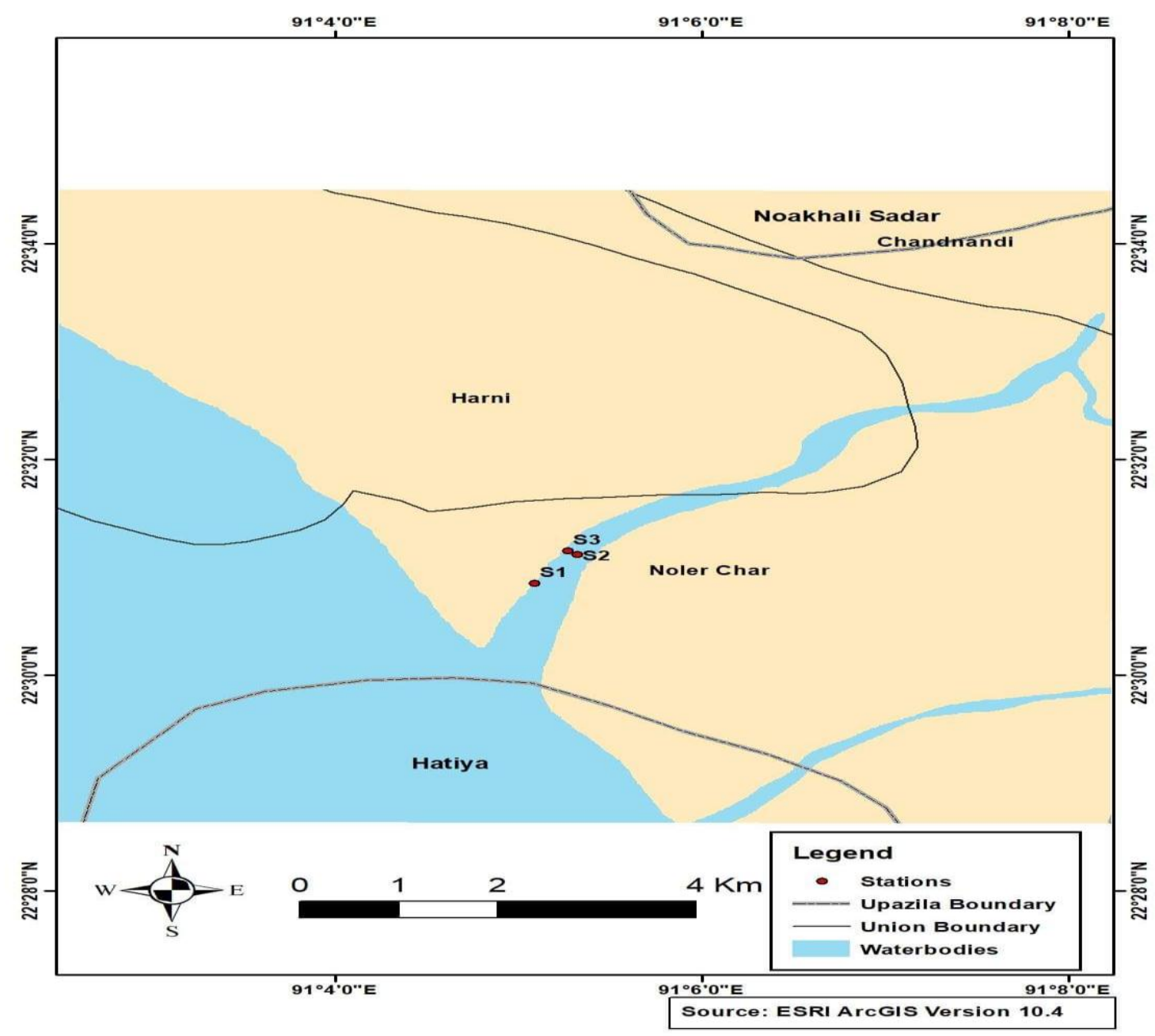

Figure 1: Location of saltmarsh areas in Noler char at Noahali Coast $(\mathrm{S1}=$ station one, $\mathbf{S 2}=$ station two and $\mathbf{S 3}=$ station three).

*(Three tidal levels were selected as High tide level (HTL), Mid tide level (MTL) and Low tide level (LTL) from each station)

\section{Collection of water and sediment sample}

The water sample was collected from the stations during the low tide to measure water temperature $\left({ }^{\circ} \mathrm{C}\right)$, salinity $(\mathrm{ppt})$ and $\mathrm{pH}, \mathrm{DO}(\mathrm{mg} / \mathrm{L})$ by a digital multi-parameter (Model no (HQ30D53315000) and company $(\mathrm{HACH})$. The sediment samples were collected by mud corer $(10 \mathrm{~cm} \times 10 \mathrm{~cm} \times 10 \mathrm{~cm})$ with an area of $0.01 \mathrm{~m}^{2}$. A Bucket was used to keep the sediment samples on the sampling spots.

\section{Sieving and sorting of the Sediment Sample}

After collecting the sediment sample, the sample was mixed into the water properly. The sediment samples were sieved through a $0.5 \mathrm{~mm}$ mesh size screen to get benthic infauna. Then the sorted infaunas were well preserved into $70 \%$ alcohol solution in small vials using small forceps for the identification. An electronic microscope (Model No. XSZ 21 05DN, China) was used to capture the picture of benthos. 


\section{Data analysis}

The number per square meter of infauna was estimated by using the following formulas Welch's method

It is calculated as

$N=\frac{0}{a s} \times 10000$ where, $\mathrm{N}=$ Number of infauna 1 sq.m of profoundal bottom, $0=$ No. of infauna per sampled area, a=Transverse area of mud corer in sq. $\mathrm{cm}$. and $\mathrm{S}=$ Number of sample taken at one sampling site.

\section{The Shannon-Wiener index of species diversity $\left(\mathrm{H}^{\prime}\right)$}

\section{It is defined as}

$\mathbf{H}^{\prime}=-\sum_{i=1}^{S}$ pilnpi where, $s=$ total number of species in the community (richness) and $p i=$ relative abundance of the $i$ th species in a plot.

\section{The Margalef's Index of Species Richness (D)}

It was be used to compare one community with another by the following formula

$$
\mathbf{D}=\frac{s-\mathbf{1}}{\ln N} \quad \text { where, } \mathrm{S} \text { is the number of taxa, and } \mathrm{n} \text { is the number of individuals }
$$

\section{The Shannon equitability (or evenness) index}

The Shannon-equitqbility index was obtained from Shannon-Wiener index. Evenness in referring to the absolute distribution of relative abundance of species at a site is computed by the following index,

\footnotetext{
$\mathrm{J}=\frac{\mathrm{H}^{\prime}}{\ln \cdot \mathrm{S}}$ Where, $\mathrm{e}=$ Evenness index, $\mathrm{H}^{\prime}=$ Shannon-Wiener value, $\mathrm{S}=$ Total number of species in the sample
}

\section{RESULTS}

\section{Environmental Characteristics}

The water quality parameters data; temperature, salinity, $\mathrm{pH}$, Dissolve oxygen (DO) recorded from all three stations of the saltmarshes areas are shown in (Table 1).

Table 1: Environmental parameters of saltmarsh in the study area

\begin{tabular}{cccc}
\hline $\begin{array}{c}\text { Stations } \\
\text { Parameters }\end{array}$ & HTL $($ Mean \pm SD $)$ & MTL $($ Mean \pm SD $)$ & LTL $($ Mean \pm SD $)$ \\
\hline Water temperature $\left({ }^{0} \mathrm{C}\right)$ & $24.2 \pm 0$ & $25.06 \pm 0.05$ & $24.3 \pm 0$ \\
\hline DO $(\mathrm{mg} / \mathrm{L})$ & $8.26 \pm 0$ & $8.08 \pm 0.02$ & $8.2 \pm 0$ \\
\hline Salinity $(\mathrm{ppt})$ & $7.73 \pm 0$ & $7.52 \pm 0.32$ & $7.72 \pm 0$ \\
\hline Water $\mathrm{pH}$ & $8.84 \pm 0$ & $8.56 \pm 0.41$ & $8.85 \pm 0$ \\
\hline
\end{tabular}

\section{Biological Characteristics \\ Species composition}

The infauna of the present study was identified up to family level and a total of 16 taxa (families) of benthic infauna were found in the three tidal levels. The study reported a total of 46000 ind. $/ \mathrm{m}^{2}$ from the sampling site with a mean abundance of $15333.33 \pm 11128.94 \mathrm{ind} / \mathrm{m}^{2}$. The most abundant family was Nereidea $\left(17300 \mathrm{ind} / \mathrm{m}^{2}\right)$. Chironomidae (11300 ind. $/ \mathrm{m}^{2}$ ) and Nereidae-1 (5800 ind. $\left./ \mathrm{m}^{2}\right)$ were also quite dominant. Among all 16 taxa (families) Nereidea (37.60\%), Nereidae-1 (12.60\%), Chironomidae 
(24.56\%), Cerambycidae (2.17\%) were found at the high tide level and mid-tide level. Portunidae (10.86\%), Shrimp larvae (5.21\%) were found in three tide levels. Mysidae $(0.20 \%)$, Nereddidae $(3.26 \%)$ and Littorinidae $(0.43 \%)$ were found high tide level. Lumbrineridae $(0.43 \%)$, Capitallidae $(0.21 \%)$, Calonoidae $(0.21 \%)$, Tubificidae $(0.65 \%)$, Pieridae $(0.65 \%)$, Spionidae $(0.21 \%)$ were found only mid-tide level. The study reported that the highest 13 taxa were found in the mid-tide level (Table 2).

Table 2. The abundance of macro-benthic families (ind. $/ \mathrm{m}^{2}$ )

\begin{tabular}{ccccccc}
\hline Family & HTL & MTL & LTL & Mean \pm SD & Total & Percentage (\%) \\
\hline Nereidae & 8900 & 8400 & 0 & $5766.66 \pm 5000.33$ & 17300 & 37.60869565 \\
\hline Nereidae-1 & 3100 & 2700 & 0 & $1933.33 \pm 1686.21$ & 5800 & 12.60869565 \\
\hline Chironomidae & 7300 & 4000 & 0 & $3766.66 \pm 3655.58$ & 11300 & 24.56521739 \\
\hline Mysidae & 100 & 0 & 0 & $33.33 \pm 57.73$ & 100 & 0.217391304 \\
\hline Nereidae- 2 & 1500 & 0 & 0 & $500 \pm 866.02$ & 1500 & 3.260869565 \\
\hline Glyceridae & 200 & 100 & 0 & $100 \pm 100$ & 300 & 0.652173913 \\
\hline Lumbrineridae & 0 & 200 & 0 & $66.66 \pm 115.47$ & 200 & 0.434782609 \\
\hline Capitallidae & 0 & 100 & 0 & $33.33 \pm 57.73$ & 100 & 0.217391304 \\
\hline Calonoidae & 0 & 100 & 0 & $33.33 \pm 57.73$ & 100 & 0.217391304 \\
\hline Tubificidae & 0 & 300 & 0 & $100 \pm 173.20$ & 300 & 0.652173913 \\
\hline Pieridae & 0 & 300 & 0 & $100 \pm 173.20$ & 300 & 0.652173913 \\
\hline Spionidae & 0 & 100 & 0 & $33.33 \pm 57.73$ & 100 & 0.217391304 \\
\hline Portunidae & 800 & 3500 & 700 & $1666.66 \pm 1588.50$ & 5000 & 10.86956522 \\
\hline Littorinidae & 200 & 0 & 0 & $66.66 \pm 115.47$ & 200 & 0.434782609 \\
\hline Shrimp larvae & 200 & 300 & 1900 & $800 \pm 953.93$ & 2400 & 5.217391304 \\
\hline Cerambycidae & 900 & 100 & 0 & $333.33 \pm 493.28$ & 1000 & 2.173913043 \\
\hline Total & 23200 & 20200 & 2600 & $15333.33 \pm 11128.94$ & 46000 & 100 \\
\hline Family found & 10 & 13 & 3 & & & \\
\hline
\end{tabular}

\section{Comparison of benthos abundance}

The highest benthic infaunas $\left(23200\right.$ ind. $\left./ \mathrm{m}^{2}\right)$ were recorded from HTL and the lowest $\left(2600\right.$ ind. $\left./ \mathrm{m}^{2}\right)$ from LTL station. The number of benthic infaunas from MTL was 23200 ind. $/ \mathrm{m}^{2}$ (Table 3).

Table 3 : Comparison of benthos abundance (ind. $/ \mathrm{m}^{2}$ ) from different tidal levels

\begin{tabular}{cccc}
\hline Family & \multicolumn{3}{c}{ Stations } \\
\cline { 2 - 4 } & HTL & MTL & LTL \\
\hline Nereidea & 8900 & 8400 & 0 \\
\hline Nereidae-1 & 3100 & 2700 & 0 \\
\hline Chironomidae & 7300 & 4000 & 0 \\
\hline Mysidae & 100 & 0 & 0 \\
\hline Nereidae-2 & 1500 & 0 & 0 \\
\hline Glyceridae & 200 & 100 & 0 \\
\hline Lumbrineridae & 0 & 200 & 0
\end{tabular}




\begin{tabular}{cccc}
\hline Calonoidae & 0 & 100 & 0 \\
\hline Tubificidae & 0 & 300 & 0 \\
\hline Pieridae & 0 & 300 & 0 \\
\hline Spionidae & 0 & 100 & 0 \\
\hline Portunidae & 800 & 3500 & 0 \\
\hline Littorinidae & 200 & 0 & 1900 \\
\hline Shrimp larvae & 200 & 300 & 0 \\
\hline Cerambycidae & 900 & 100 & 2600 \\
\hline Total & 23200 & 20200 &
\end{tabular}

\section{Diversity indices}

For analyzing the diversity of benthic infauna, the commonly used tool is diversity index. The highest individuals index of benthic infauna value was 8800 found in the high tide level station HTL1 and the lowest value (500) reported in the low tide level station LTL3 (Table 4).

Table 4. Different diversity indices at three tidal level (present study)

\begin{tabular}{cccccccccc}
\hline & HTL1 & HTL2 & HTL3 & MTL1 & MTL2 & MTL3 & LTL1 & LTL2 & LTL3 \\
\hline Taxa (S) & 9 & 6 & 3 & 8 & 8 & 5 & 2 & 1 & 1 \\
\hline Individuals & 8800 & 7100 & 7300 & 8400 & 7600 & 4200 & 1400 & 700 & 500 \\
\hline $\begin{array}{c}\text { Simpson (1- } \\
\text { D) }\end{array}$ & 0.7268 & 0.7804 & 0.5791 & 0.6811 & 0.769 & 0.6893 & 0.5 & 0 & 0 \\
\hline Shannon (H) & 1.563 & 1.617 & 0.9676 & 1.475 & 1.631 & 1.321 & 0.6931 & 0 & 0 \\
\hline $\begin{array}{c}\text { Evenness } \\
\left(\mathrm{e}^{\wedge} \mathrm{H} / \mathrm{S}\right)\end{array}$ & 0.5305 & 0.8395 & 0.8772 & 0.5464 & 0.6385 & 0.7497 & 1 & 1 & 1 \\
\hline Margalef & 0.8808 & 0.5638 & 0.2248 & 0.7747 & 0.7834 & 0.4795 & 0.138 & 0 & 0 \\
\hline $\begin{array}{c}\text { Equitability } \\
(\mathrm{J})\end{array}$ & 0.7115 & 0.9024 & 0.8808 & 0.7094 & 0.7842 & 0.821 & 1 & 0 & 0 \\
\hline
\end{tabular}

The Simpson_1-D index of benthic infauna showed the highest value was 0.7804 found in the high tide level HTL2 station and the lowest value was 0 found in the low tide level station LTL3 (Figure 2 and Table 4).

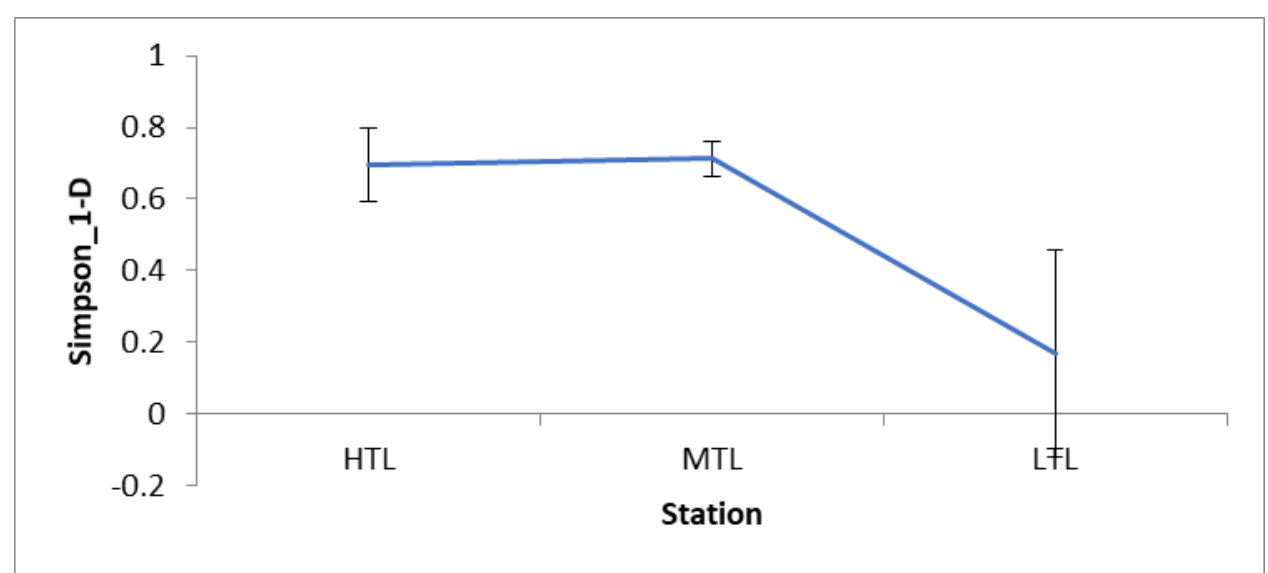

Figure 2: Station wise distribution of Simpson (1-D) index during the present study. Error bars indicate standard deviation. 
The Shannon_H index of benthic infauna described the highest value was 1.631 found in the mid-tide level station MTL2 and the lowest value was 0 found at the low tide level station LTL3. The Shannon_H index was higher in the high tide level and lowered in the low tide level (Figure 3 and Table 4).

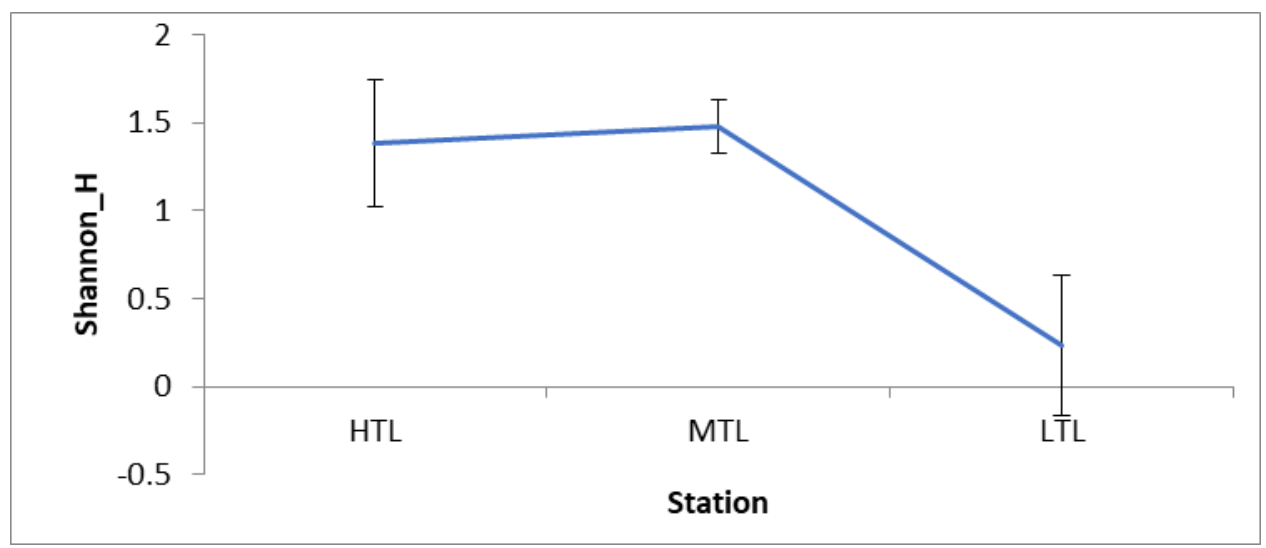

Figure 3: Station wise distribution of Shannon $\left(\mathrm{H}^{\prime}\right)$ index during the present study. Error bars indicate standard deviation.

The Evenness_e^ $\mathrm{e}^{\wedge} \mathrm{S}$ index of benthic infauna demonstrated that the highest value 1 was in the low tide level station LTL1,2,3 and the lowest value was 0.5305 in the high tide level HTL1 station. The Evenness_e ${ }^{\wedge} \mathrm{H} / \mathrm{S}$ index was higher in the low tide level and lowered at the mid-tide level. (Figure 4 and Table 4).

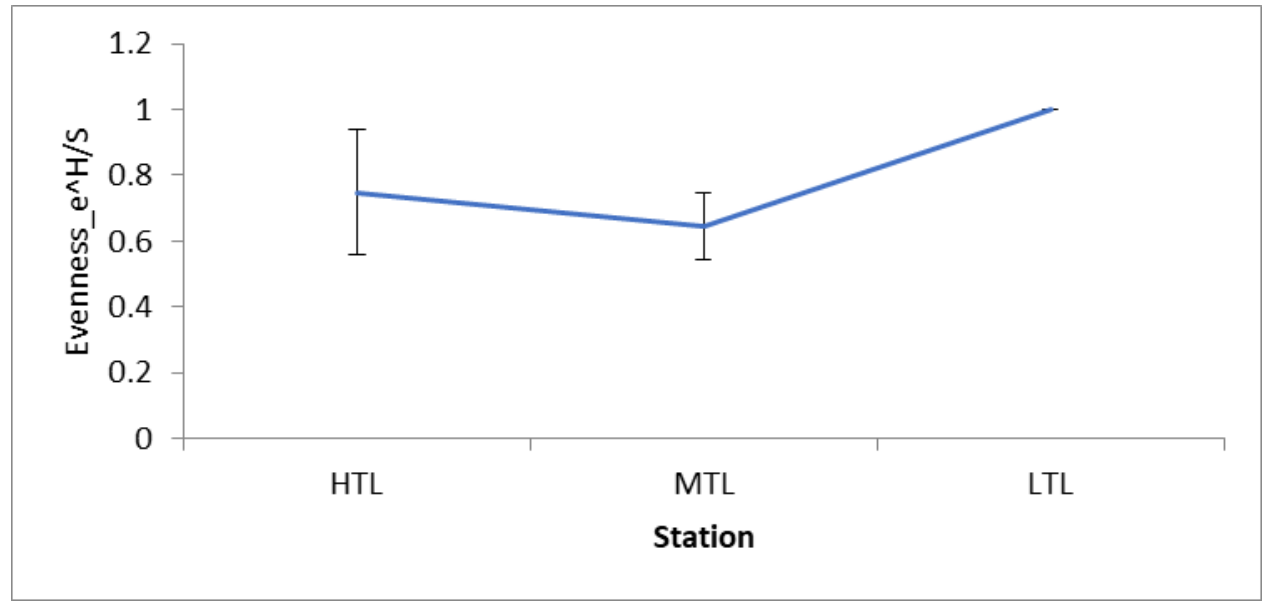

Figure 4: Station wise distribution of Evenness $\left(e^{\wedge} \mathbf{H} / S\right)$ index. Error bars indicate standard deviation.

The Margalef index of benthic infauna showed the highest value was 0.8808 in the high tide level HTL1 station and the lowest value was 0 in the low tide level LTL3 station. The overall study indicates that the Margalef index was higher in the mid-tide level (Figure 5 and Table 4). The Equitability_J index of benthic infauna described the highest 
value was 1 in the low tide level station LTL1 and the lowest value was 0 in the low tide level LTL2 and 3 station (Table 4).

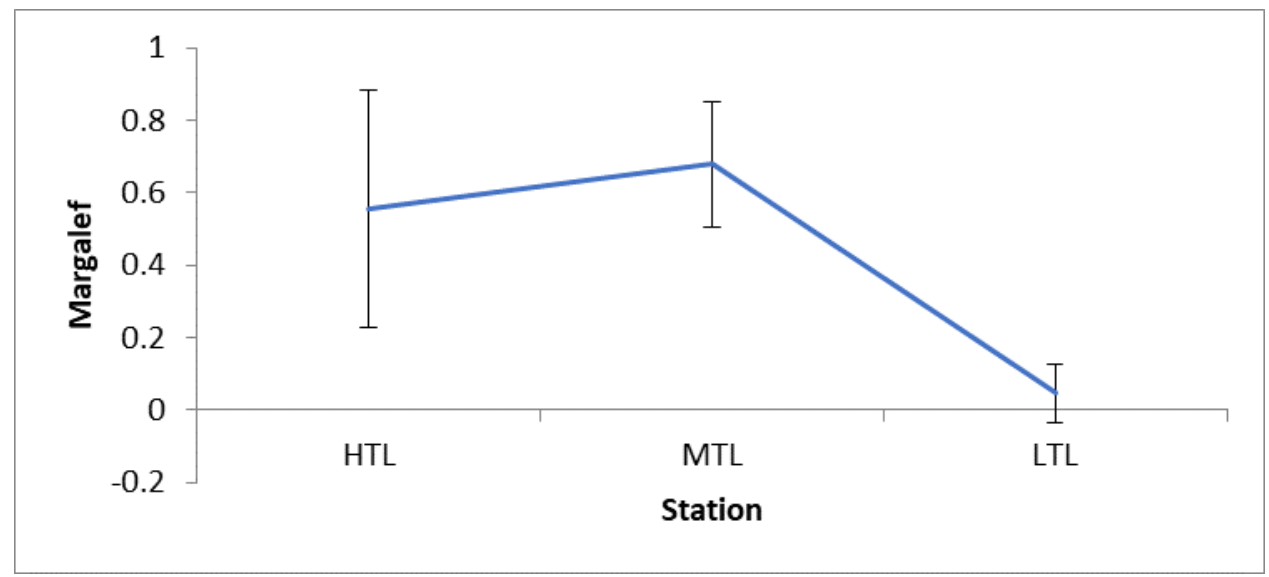

Figure 5: Station wise distribution of Margalef index during the present study. Error bars indicate standard deviation.

\section{Diversity Profile}

Diversity profile showed clear differences in the diversity of benthic infauna of the recent study, while data were presented as a tidal variation. The diversity was high in the midtide level station and low in the low tide level station (Figure 6).

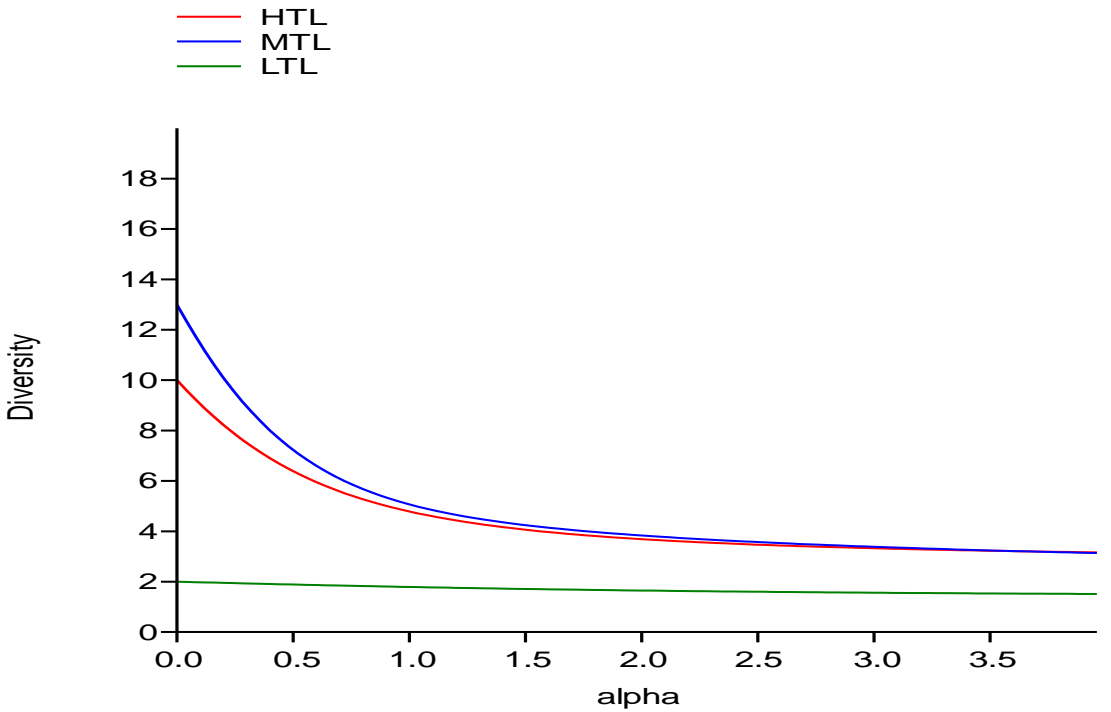

Figure 6: Diversity profile of macrobenthic infauna during the sampling station ( HTL $=$ High tide level, $M T L=$ Mid tide level and $L T L=L o w$ tide level).

\section{Spearman's Rank Correlation analysis}

The Spearman's Rank Correlation analysis physico-chemical and biological parameters indicate that they were not significant $(\mathrm{p}>0.05)$ with the exception of some parameters. The Taxa (S) and DO were highly negatively significant $(\mathrm{p}<0.01)$. The Simpson $(1-\mathrm{D})$ 
and temperature, Shannon $(\mathrm{H})$ and DO, Evenness $\left(\mathrm{e}^{\wedge} \mathrm{H} / \mathrm{S}\right)$ and salinity, Margalef and DO were negatively significant $(\mathrm{p}<0.05)$. The Taxa $(\mathrm{S})$ and temperature were highly significant ( $\mathrm{p}<0.01)$. The Simpson (1-D) and DO, Shannon $(H)$ and temperature, Margalef and temperature were significant $(\mathrm{p}<0.05)$ respectively.

It also indicates that they were weakly correlated $(0<\mathrm{r}<0.25)$. The DO and Equitability (J), Salinity and $\mathrm{pH}$, Salinity and Individuals, Salinity and Equitability (J), pH and Equitability (J), Taxa (S) and Equitability (J), Shannon (H) and Equitability (J), Margalef and Equitability $(\mathrm{J})$ were intermediate correlation $(0.25 \leq \mathrm{r}<0.75)$. The temperature and Taxa (S), temperature and Individuals, temperature and Simpson (1-D), temperature and Shannon $(\mathrm{H})$, temperature and Evenness $\left(\mathrm{e}^{\wedge} \mathrm{H} / \mathrm{S}\right)$, temperature and Margalef, DO and Taxa (S), DO and Individuals, DO and Simpson (1-D), DO and Shannon (H) was a strong correlation $(0.75 \leq \mathrm{r}<1)$ respectively.

Table 5. Spearman's Rank Correlation analysis among the measured parameters

\begin{tabular}{cccccccccccc}
\hline 0 & Tem. & DO & Sal. & $\mathrm{pH}$ & $\mathrm{S}$ & Ind. & $1-\mathrm{D}$ & $\mathrm{H}$ & $\mathrm{e}^{\wedge} \mathrm{H} / \mathrm{S}$ & Marg. & $\mathrm{J}$ \\
\hline Tem. & 0 & 0.00 & 0.00 & 0.17 & 0.98 & 0.77 & 0.93 & 0.93 & 0.76 & 0.97 & 0.58 \\
\hline $\mathrm{DO}$ & -1 & 0 & 0.00 & 0.17 & 0.98 & 0.77 & 0.93 & 0.93 & 0.76 & 0.97 & 0.58 \\
\hline Sal. & -0.95 & 0.95 & 0 & 0.37 & 0.81 & 0.55 & 0.83 & 1 & 0.95 & 0.88 & 0.60 \\
\hline $\mathrm{pH}$ & -0.51 & 0.51 & 0.34 & 0 & 0.05 & 0.09 & 0.06 & 0.05 & 0.02 & 0.05 & 0.71 \\
\hline $\mathrm{S}$ & 0.00 & -0.00 & 0.09 & -0.69 & 0 & 0.00 & 0.00 & 0.00 & 0.00 & 0.00 & 0.70 \\
\hline Ind. & -0.12 & 0.12 & 0.23 & -0.61 & 0.94 & 0 & 0.05 & 0.01 & 0.00 & 0.00 & 0.75 \\
\hline 1-D & -0.03 & 0.03 & 0.08 & -0.66 & 0.82 & 0.67 & 0 & 0.00 & 0.03 & 0.00 & 0.24 \\
\hline H & 0.03 & -0.03 & 0 & -0.68 & 0.89 & 0.77 & 0.96 & 0 & 0.01 & 0.00 & 0.38 \\
\hline $\mathrm{e}^{\wedge} \mathrm{H} / \mathrm{S}$ & -0.12 & 0.12 & -0.01 & 0.76 & -0.96 & -0.91 & -0.73 & -0.80 & 0 & 0.00 & 0.93 \\
\hline Marg. & 0.01 & -0.01 & 0.062 & -0.68 & 0.99 & 0.92 & 0.84 & 0.91 & -0.95 & 0 & 0.67 \\
\hline J & -0.20 & 0.20 & 0.20 & -0.13 & 0.14 & 0.12 & 0.42 & 0.32 & 0.03 & 0.15 & 0 \\
\hline & & & & & & & & & & &
\end{tabular}

A brief comparison of microbenthic diversity indices as described in the following table (Table 6). Present research work addressed 16 taxa from the study site while a maximum of 52 taxa was recorded from Twai river, India (Chowdhary et al., 2013) and minimum of 10 taxa were reported from Meghna river estuary, Bangladesh (Hossain et al., 2018).

Table 6. Comparison of diversity indices of macrobenthos in tropical regions

\begin{tabular}{ccccccccc}
\hline Area & $\begin{array}{c}\text { Taxa } \\
(\mathrm{S})\end{array}$ & $\begin{array}{c}\text { Ind. (max- } \\
\text { min/station) }\end{array}$ & 1-D & $\mathrm{H}$ & $\mathrm{e}^{\wedge} \mathrm{H} / \mathrm{S}$ & Marg. & $\mathrm{J}$ & References \\
\hline $\begin{array}{c}\text { Noakhali coast, } \\
\text { Bangladesh }\end{array}$ & 16 & $8800-500$ & $0.78-0$ & $1.63-0$ & $1-0.53$ & $0.88-00$ & $0.90-0$ & $\begin{array}{c}\text { Present study } \\
(2020)\end{array}$ \\
\hline $\begin{array}{c}\text { Mouri River } \\
\text { Bangladesh }\end{array}$ & 16 & $1040-630$ & - & - & - & - & - & $\begin{array}{c}\text { Khan } \text { et al. } \\
(2007)\end{array}$ \\
\hline Tawi river, India & 52 & $3996-2367$ & - & $\begin{array}{c}2.759- \\
0.623\end{array}$ & - & $\begin{array}{c}2.724- \\
1.03\end{array}$ & $\begin{array}{c}0.96- \\
0.26\end{array}$ & $\begin{array}{c}\text { Chowdhary et } \\
\text { al. }(2013)\end{array}$ \\
\hline $\begin{array}{c}\text { Karnafuli estuary, } \\
\text { Bangladesh }\end{array}$ & 33 & - & - & - & - & - & - & $\begin{array}{c}\text { Islam } \text { et al. } \\
(2013)\end{array}$ \\
\hline Meghna River, & 17 & $7658.7-$ & - & - & $0.95-$ & - & - & $\begin{array}{c}\text { Sharif et al. } \\
\text { Negharif }\end{array}$
\end{tabular}




\begin{tabular}{|c|c|c|c|c|c|c|c|c|}
\hline Bangladesh & & 208.1 & & & 0.2 & & & (2017) \\
\hline $\begin{array}{l}\text { Hatiya and Nijhum } \\
\text { Dweep } \\
\text { Islands,Bangladesh }\end{array}$ & 10 & $4511-433$ & - & - & - & - & - & $\begin{array}{l}\text { Asadujjaman } \\
\text { et al. (2012) }\end{array}$ \\
\hline $\begin{array}{l}\text { Amazonian } \\
\text { saltmarshes }\end{array}$ & 51 & 4244 & - & - & - & - & - & $\begin{array}{l}\text { Braga et al. } \\
\quad(2011)\end{array}$ \\
\hline $\begin{array}{l}\text { Yangtze River } \\
\text { Estuary, China }\end{array}$ & 23 & 30539 & - & - & - & - & - & $\begin{array}{l}\text { Chen } \text { et al. } \\
\text { (2009) }\end{array}$ \\
\hline $\begin{array}{l}\text { Greater Noakhali- } \\
\text { Bangladesh }\end{array}$ & 14 & 5481 & $\begin{array}{l}0.75- \\
0.42\end{array}$ & $\begin{array}{l}1.64- \\
0.77\end{array}$ & - & $\begin{array}{l}1.23- \\
0.45\end{array}$ & $\begin{array}{c}0.84- \\
0.51\end{array}$ & $\begin{array}{l}\text { Sarker et al. } \\
\text { (2016) }\end{array}$ \\
\hline $\begin{array}{c}\text { Bakkhali river } \\
\text { estuary, } \\
\text { Bangladesh }\end{array}$ & 28 & $4488-1555$ & $\begin{array}{c}0.93- \\
0.78\end{array}$ & $\begin{array}{c}2.78- \\
1.91\end{array}$ & $\begin{array}{l}0.85- \\
0.61\end{array}$ & $\begin{array}{c}2.50- \\
1.09\end{array}$ & $\begin{array}{c}0.94- \\
0.80\end{array}$ & $\begin{array}{l}\text { Sarker et al. } \\
\quad(2016)\end{array}$ \\
\hline $\begin{array}{l}\text { Meghna estuarine } \\
\text { bed, Bangladesh }\end{array}$ & 20 & $12701-9$ & - & - & - & - & - & $\begin{array}{c}\text { Hossain et al. } \\
\text { (2009) }\end{array}$ \\
\hline $\begin{array}{c}\text { Meghna river, } \\
\text { Bangladesh }\end{array}$ & 8 & $3358-44$ & - & - & - & $\begin{array}{l}0.25- \\
0.24\end{array}$ & - & $\begin{array}{l}\text { Hossain et al. } \\
\text { (2018) }\end{array}$ \\
\hline
\end{tabular}

\section{DISCUSSION}

\section{Environmental parameters}

The saltmarsh which was selected namely Noler char in Noakhali was influenced by the tidal flats of the Meghna River estuary. The sub-surface water temperature varied 24.2$25.1^{\circ} \mathrm{C}$ during the study period at a different station and tidal level. Netto and Lana, 1997 recorded that the temperature was $19-34^{\circ} \mathrm{C}$ at a different station in a euryhaline saltmarsh in Paranaguá Bay (SE Brazil) were quite different from the present findings. This variation might be occurred due to geographical location between saltmarsh of Noakhali coast and euryhaline saltmarsh in Paranaguá Bay.

The salinity of the present study was $7.52-7.73 \mathrm{ppt}$ in January on the saltmarsh. Sharif et al., (2017) recorded the salinity of Meghna estuary was 15 ppt in the post-monsoon. Berrêdo et al., 2008, Magalhães et al. 2009, Sousa et al., 2009 reported that mean values of surface water salinity in the estuary along the Pará coast vary widely, from near 0 to 40. The present investigation defined significant variation. This variation occurred due to a decrease in freshwater intrusion. Minello, (1994) described the water salinities were 2-3 ppt, during the study period on the salt marsh located on the Galveston bay of Texas. Barrons et al., (2008) defined the superficial water salinity varied between 0.6 and 30.8 winter at all stations in Brazilian saltmarsh.

During the study period, the water $\mathrm{pH}$ varied from 8.09 to 8.85 at all stations was slightly different from the findings of Barrons et al. (2008) as they recorded the range of $\mathrm{pH}$ was 6.62 to 8.14 in the Brazilian saltmarsh. Sarker et al ., (2016) recorded the water pH 7.15 to 8.75 in post-monsoon season has a similar agreement to the current study.

Sharif et al., (2017) recorded that the range of DO was 1.9 to $2.8 \mathrm{mg} / \mathrm{L}$ in the postmonsoon. In this present work, the DO was observed 8.05 to 8.26 at all the stations during the study period. This variation occurred due to erosion and tidal effect, which fluctuates the concentration of DO. 


\section{Benthic infaunal assemblages}

Wang et al. (2010) recorded 29 species of macrobenthos at the eight sampling marshes in the Yangtze Estuary, China. Tang and Kristensen (2010) found a total of 20 macrobenthos species (14 infaunal and 6 epifaunal taxa). Vinagre et al. (2008) found 22 taxa (family) in the saltmarsh of Tagus estuary. In the current study, a total of 16 taxa were found in the present investigation which was similar to other findings. Alam, (1993) reported 71 species from the Halishahar coast, Bangladesh by using $500 \mu \mathrm{m}$ mesh screen. Braga et al. (2011) recorded 51 taxa (family) in Amazon coast saltmarshes. This finding was reversed in the present investigation. The dissimilarity might be occurred due to geographical change in those areas.

Braga et al. (2011) examined 4244 individuals macroinfaunal assemblages associated with Amazonia saltmarshes. Silva et al., (2006) defined a total of 18140 individuals belonging to 41 taxa (family) were collected. Edgar and Barrett (2002) showed that a total of 115861 individuals belonging to 396 invertebrate taxa (family) were collected at the 55 locations in 48 estuaries investigated. A total of 46000 individuals were recorded in the present investigation. The phenomenon was reverse in the above findings. It was possibly due to sediment and environmental characteristics.

Braga et al., (2011) reported the Malacostaca was the dominant class with $63.9 \%$ of the total abundance. Wang et al., (2010) recorded the gastropods were the dominant group in the saltmarsh in the Yangtze Estuary China but the present work reported Polychaeta was the dominant group. This might be occurred due to the composition of sediment particles. Ansari (1984); Minello et al. (1994) and Tang and Kristensen (2010) reported that Polychaeta was the most dominant group in seagrass bed at Minicoy, Spartina alterniflora marsh in the Galveston Bay system of Texas and Spartina anglica in the Danish Wadden Sea respectively. That showed fair agreement with the present investigation.

\section{Environmental parameters and benthic infaunal relationship}

In the present study, some environmental variables that were correlated with the benthic infaunal Abundance and diversity. Saltmarshes gather the abundance of taxa with high salinity (Braga et al., 2011). Salinity and temperature have been positively correlated with greater abundance and the number of taxa of macrobenthos along the Amazon coast (Rosa Filho et al., 2011). These results support the present study. The density and richness of macrobenthic organisms usually increase with salinity in most of the tropical and subtropical estuaries (Montagna and Kalke 1992). The results of the study showed that abundance was positively correlated with salinity. Gaskill (2014) reported that benthic macro-invertebrate richness is significantly correlated with $\mathrm{pH}(\mathrm{p}=0.034)$ and richness decreased because of lower $\mathrm{pH}$. But present work found no significant relationship between water $\mathrm{pH}$ and richness.

\section{CONCLUSION}

This is the first study of its kinds to study the varation of macroinfauna in the saltmarsh habitat of Bangladesh. From the study it was observed environmental parameters varied across three tidal levels. The taxa, Nereidae and Chironomidae were mostly dominant in 
all the three tidal levels. The highest number of similar species were noticed at the substations of LTLs and the maximum Shannon diversity $\left(\mathrm{H}^{\prime}\right)$ index was at the sub-station MTL2. The diversity profile value was high at the mid-tide level. The Simpson indix and DO, Shannon $\left(\mathrm{H}^{\prime}\right)$ and Margalef index and temperature were significantly correlated $(\mathrm{p}<0.05)$. It was also observed that almost all diversity indices showed a strong correlation with temperature $(0.75 \leq \mathrm{r}<1)$. The information can be used for biodiversity conservation of the study area.

\section{ACKNOWLEDGEMENT}

We would like to thank the Department of Fisheries and Marine Science of Noakhali Science and Technology University (NSTU), for providing adequate laboratory facilities.

\section{REFERENCES}

Alam, M. E. (1993). Ecology of the Intertidal Macrobenthos of Halishahar Coast, Chittagong Bangladesh (Doctoral dissertation, PhD thesis Department of Zoology, University of Chittagong).

Ansari, Z. A. (1984). Benthic macro and microfauna of seagrass (Thalassia hemprichii) bed at Minicory, Lakshadweep. Indian Journal of Marine Science, 13:126127.

Asadujjaman, M.; Hossain, M. B.; Shamsuddin, M.; Amin, M. A. and Azam, A. K. M. (2012). Occurrence and abundance of macrobenthos of Hatiya and Nijhum Dweep Islands, Bangladesh. Middle-East Journal of Scientific Research, 11(2):184-188.

Barrons, F.; Hatge, V.; Figureueiredo, M. B.; Magalhaes, W.F.; Dorea, H. S. and Emidio, E.S. (2008). The structure of the benthic macrofaunal assemblages and sediment characteristics of the Paraguacu estuarine system, NE, Brazil. Estuarine, Coastal and Shelf Science, 78 (4):753-762.

Berredo, J. F.; Costa, M. L. and Progene, M. D. P. S. (2008). Efeitos das variações sazonais do clima tropical úmido sobre as águas e sedimentos de manguezais do estuário do rio Marapanim, costa nordeste do Estado do Pará. Acta Amaz, 38(3):473-482.

Braga, C. F.; Monteiro, V. F.; Rosa-Filho, J. S. and Beasley, C. R. (2011). Benthic macroinfaunal assemblages associated with Amazonian saltmarshes. Wetlands Ecology and Management, 19(3):257-272.

Cekanovskaia, O. V. (1962). Water Oligochaetas of SSSR, pp185-186.

Chen, Z.; Guo, L.; Jin, B.; Wu, J. and Zheng, G. (2009). Effect of the exotic plant Spartina alterniflora on macrobenthos communities in salt marshes of the Yangtze River Estuary, China. Estuarine, Coastal and Shelf Science, 82(2):265-272.

Chowdhary, S. and Sharma, K. K. (2013). Evaluation of Macrobenthic invertebrates in the longitudinal profile of a river (Tawi), originating from Shivalik hills. Journal of Global Biosciences, 2(1):31-39. 
Edgar, G. J. and Barrent , N. S. (2002). Benthic macrofauna in Tasmanian estuaries: scales of distribution and relationships with environmental variables. Journal of Experimental Marine Biology and Ecology, 270(1):1-24.

Filho, J. R.; Gomes, T. P.; Almeida, M. F. and Silva, R. F. (2011). Benthic fauna of macrotidal sandy beaches along a small-scale morphodynamic gradient on the Amazon coast (Algodoal Island, Brazil). Journal of Coastal Research, pp435-439.

Gaskill, J. A. (2014). Examining the effects of pH and Macrophyte Diversity on Benthic Macroinvertebrate Assemblages in Adirondack Lakes. Honor's Thesis Paper: p35.

Gogina, M. and Zettler, M. L. (2010). Diversity and distribution of benthic macrofauna in the Baltic Sea: data inventory and its use for species distribution modeling and prediction. Journal of Sea Research, 64(3):313-321.

Hossain, M. B.; Das, N. G. and Sharmeen, R. (2009). Seasonal and spatial distribution of macrozoobenthos of the Meghna River estuarine bed. International Journal of Sustainable Agriculture Technology, 5:11-16.

Hossain, M. J.; Sarker, M. J.; Uddin, M. N.; Islam, A.; Tumpa, I. J. and Hossain, Z. (2018). Macrobenthos presence in the estuarine waters of the Meghna river, Ramghati, Laksmipur, Bangladesh. World Applied Sciences Journal, 36(4):598604.

Hutchinson, G. E. (1993). A treatise on limnology. Volume IV: The zoobenthos. YH Edmondson.

Islam, M. S.; Sikder, M. N. A.; Al-Imran, M.; Hossain, M. B.; Mallick, D. and Morshed, M. M. (2013). Intertidal macrobenthic fauna of the Karnafuli estuary: relations with environmental variables. World Applied Sciences Journal, 21(9):1366-1373.

Japoshvili, B.; Pataridze, A.; Bozhadze, M.; Shubitidze, Z. and Gioshvili, M. (2015). Littoral Benthic Macroinvertebrates and Their Correlation with the Chemical Composition of Water in the Tbilisi Reservoir. Proceedings of the Institute of Zoology, 24.

Jones C.G.; Lawton J. H. and Shachak M. (1994). Organisms as Ecosystem Engineers. In: Ecosystem Management. Springer, New York, NY. https://doi.org/10.1007/978-1-4612-4018-1_14

Khan, A. N.; Kamal, D.; Mahmud, M. M.; Rahman, M. A. and Hossain, M. A. (2007). Diversity, distribution and abundance of benthos in Mouri River, Khulna, Bangladesh. International Journal of Sustainable Crop Production, 2(5):19-23.

MAgalhães, A.; Bessa, R. D. S. C.; Pereira, L. C. C. and Costa, R. M. D. (2009). Variação temporal da composição, ocorrência e distribuição dos Copepoda do estuário do Taperaçu, Pará, Brasil. Boletim do Museu Paraense Emílio Goeldi Ciências Naturais, 4(2):133-148.

McLusky, D. S. and Elliot, D. (2006). The Estuarine Ecosystem: Ecology, Threats and Management. 3rd edn. Oxford University Press, Oxford, 214. 
Minello, T. J.; Zimmerman, R. J. and Medina, R. (1994). The importance of edge for natant macrofauna in a created salt marsh. Wetlands, 14(3):184-198.

Montagna, P. A. and Kalke, R. D. (1992). The effect of freshwater inflow on meiofaunal and macrofaunal populations in the Guadalupe and Nueces Estuarines, Texas. Estuaries, 15(3):307-326.

Netto, S. A. and Lana, P. C. (1997). Intertidal zonation of benthic macrofauna in a subtropical salt marsh and nearby unvegetated flat (SE, Brazil). Hydrobiologia, 91: 531-536.

Palmer, I. M. A. (1997). Biodiversity and Ecosystem Processes. Ambio, 26(8):556-562.

Pramanik, M. A. H. (1988). Methodologies and techniques of studying coastal systemsSPARRSO case studies, CARDMA II:122-138.

Sarker, J.; Patwary, S. A.; Uddin, B.; Hasan, M.; Tanmay, M. H.; Kanungo, I. and Parvej, M. R. (2016). Macrobenthic community structure-an approach to assess coastal water pollution in Bangladesh. Fisheries and Aquaculture Journal, 7:2-10

Sharif, A. S. M.; Islam, S., and Islam, M. (2017). Spatial and Temporal Environmental Variable Effect of Lower Meghna River \& Its Estuary on Macrobenthic Fauna, Bangladesh. International Journal of Marine Science, 7(2):102-113.

Silva, G.; Costa, J. L.; de Almeida, P. R. and Costa, M. J. (2006). Structure and dynamics of a benthic invertebrate community in an intertidal area of the Tangus estuary, western Portugal: a six year data series. In Marine Biodiversity ,Springer, Dordrecht, $p p$. 115-128.

Snelgrove, P. V. (1998). The biodiversity of macrofaunal organisms in marine sediments. Biodiversity \&Conservation, 7(90):1123-1132.

Sousa, E. D.; Costa, V. D.; Pereira, L. C. C. and Costa, R. D. (2009). Variação temporal do fitoplâncton e dos parâmetors hidrológicos da zona arrebentação da Ilha Canela. Acta Botanica Brasilica, 23(4):1084-1095.

Tang, M. and Kristensen, E. (2010). Associations between macrobenthos and invasive cordgrass, Spartina anglica, in the Danish Wadden Sea. Helgoland marine research, 64(4):321.

Vinagre, C.; Fonseca, V.; Maia, A.; Amara, R. and Cabral, H. (2008). Habitat specific growth rates and condition indices for the sympatric soles Solea solea (Linnaeus, 1758) and Solea senegalensis Kaup 1858, in the Tagus estuary, Portugal, based on otolith daily increments and RNA- DNA ratio. Journal of Applied Ichthyology, 24(2):163-169.

Wang, R.; Yuan, L. and Zhang, L. (2010). Impacts of Spartina alterniflora invasion on the benthic communities of salt marshes in the Yangtze Estuary, China. Ecological Engineering, 36(6):799-806.

Warwick, R. M. (1993).Environmental impacts studies on marine communities: pragmatical considerations. Australian Journal of Ecology, 18:63-80. 